\title{
Policing Racial Fantasy in the Far West of New South Wales ${ }^{1}$
}

\author{
Barry Morris \\ University of Newcastle
}

\begin{abstract}
In the 1980s, the Far West of New South Wales appeared as a flashpoint for racial tension and conflicts between Aboriginal people and the police. A number of direct confrontations occurred. At the time, attention to Aboriginal/police relations was under constant media scrutiny as pressure mounted for a Royal Commission into Aboriginal deaths in custody. Yet, even in national terms, the incidence of racial tension was abnormally high. This paper seeks to explore the social context of some of these events and to analyse the cultural and social questions they give rise to in terms of racial tensions in new ways. The tracing of the sociological categories of race and their inequitable consequences seemed less important than the local performative dynamics of race. The article seeks to explore a world where rumour and gossip, fantasy and violence add significantly to the complexity of social relations and in a manner not adequately encompassed by sociological assumptions of race.
\end{abstract}

Abject. It is something rejected from which one does not part, from which one does not protect oneself as from an object. Imaginary uncanniness and real threat, it beckons to us and ends up engulfing us (Kristeva 1982:4).

One of the more arresting details to emerge from the national investigation into Aboriginal deaths in police custody, held in Australia in the late 1980s, was the fear expressed by police of an Aboriginal insurrection at a time when the Australian nation was collectively celebrating the bicentenary of its European origins. In investigating the particular death of Lloyd Boney, the Royal Commission into Aboriginal Deaths in Custody (RCIADIC) ${ }^{2}$ found unrelated evidence of the state of siege that haunted those policing the Far West region of New South Wales. The evidence appeared as an aside, produced to shed light on why members of the police Tactical Response Group had been brought to the small rural town of Brewarrina in January, 1988. The reports were recorded under the title of 'Bicentenary Celebrations'. Four separate police intelligence reports had been filed which assessed the racial situation in the Far West and asserted that an armed Aboriginal uprising was being planned to coincide with the Bicentennial celebrations. Two of the intelligence reports had been filed by a police constable at Brewarrina on 16th November, 1987 and two further separate reports followed on the 2 nd of November and the 12th of December, 1987. Commissioner Wootten commented that the reports reveal a 'completely unjustified paranoia on the part of local police... a willingness to report completely unsourced gossip and to misinterpret quite innocent events in amazing ways' (Wootten 1991b:162).

The constable's report was based on his observation of two Aboriginal men sitting on the bonnet of a car in the bush. The report stated, 'this is a suspicious circumstance as this is almost totally an unused track' (ibid.: 164). The men were 'known aboriginal activists who, 
although not vocal in their beliefs, do make it obvious that they are pro-Aboriginal and perhaps anti-police' (ibid.:164). Being 'pro-Aboriginal' not only made them 'perhaps antipolice', but made them suspected participants in an Aboriginal conspiracy to disrupt the 1988 Bicentenary. The report states:

It is also believed by Brewarrina police that they may be holding meetings there on a regular basis for an unknown purpose. One possible reason is to organise protests or similar disturbances for the 1988 Bicentenary, which it is believed that there could be trouble in the western part of the state (Brewarrina, Bourke, Walgett). (ibid.:164)

The constable's concerns were corroborated in another police intelligence report, which reveals the widespread consensus this conspiracy theory received. This unsourced report from Dubbo was headed 'Bicentennial Celebration', and gave further credibility to these racial fantasies. It stated:

Information... received that aborigines within Bourke, Brewarrina, Walgett and Moree areas have come into possession of a large number of firearms. Informant stated that the firearms were purchased in a crate through $\mathbf{M}$. Mansell by use of government funding. Believed to be hidden for use in 1988 (ibid.:162).

This report travelled a little further down the road of paranoid delusions by raising the spectre of international gun running in the Far West. 'M. Mansell' referred to Michael Mansell, who was a member of the self proclaimed Aboriginal Provisional Government and regarded as an 'Aboriginal activist'. More importantly in this context, Mansell had recently returned from a trip to Libya, regarded at the time as a 'renegade' nation which supported international terrorism. The spectre was raised by inference of Aboriginal terrorism seeking to violently disrupt the Bicentenary celebrations. There were, in fact, no violent disturbances during the Bicentennial celebrations.

The contents of these reports do not simply reflect racial paranoia in the minds of a couple of police officers and their informants, but reveal, in their acceptance by others, a considerable degree of racial paranoia amongst police in the region in 1987. The reports were taken seriously enough by the police intelligence to deploy four TRG officers in Brewarrina in January, 1988, 'apparently as a result of the fears concerning the possibility of an armed uprising of Aboriginal people in the Bicententary year' (ibid.:165).

The incident that raised the Constable's suspicions, was later explained by the man named in the report, Mr Tombo Winters, at the Royal Commission hearing in Brewarrina. In the courtroom setting, the explanation was quite disarming. Mr Winters revealed that another Aborigine, Mr Clarke, had gone fishing and his car had broken down (ibid.:164). $\mathrm{Mr}$ Clarke had walked to town for assistance and $\mathrm{Mr}$ Winters obliged, only to have his own car run out of petrol. Mr Winters in turn walked back to town to get petrol and then got a lift from another man back to his car before he proceeded to tow Mr Clarke's car back to town (ibid.:164-165). The whole incident resembled a comedy of errors rather than a conspiracy to terrorise. As Mr Winters quipped in the witness box, 'If every time you help somebody you are going to get this kind of stuff, you'd feel careful about helping people wouldn't you?' (ibid.:164-165). Mundane inconvenience and assistance underwent a doubling of meaning. The investment of this familiar and mundane incident with such an excess of meaning requires explanation.

These police intelligence reports were based upon police informants and direct police observations. They created an expectation of an armed racial uprising erupting in Brewarrina and neighbouring towns. The bicentennial paranoia objectifies in a singular instance something that can be traced to many similar examples, that is, the racial struggle to maintain the 
dichotomies of self/community and Other. This struggle, I argue, is shaped by a transgressive fantasy of the reversal of a hierarchy of power. It is tempting to suggest further that these are the repressed memories of the originary dispossession that have been so successfully removed from national consciousness that they can only return in the form of a nightmare.

At one level, my interest here is with relations of violence and the real and imagined spectres of violence that animated relations between police and Aborigines in the $1980 \mathrm{~s}$. But a more specific concern is with the interplay between reality and the imagination. The social importance of this interplay explains a number of the paradoxes that exist at the heart of the forms of governance of the Far West. There is, for example, as Hogg has argued more generally, an 'overwhelming preoccupation with petty public order offences' (1991:3) especially in Aboriginal communities in the Far West. The excessive concentration of detentions in the Far West region is revealed in the 1986 statistic that 41 per cent of all Aboriginal detentions in NSW were made in the towns of Brewarrina and Walgett (Cunneen and Robb 1987:203). Public order offences predominate. The charge of drunkenness accounted for 76 per cent of arrests (ibid.: 199). When combined with 'other public order offences, offensive manner, unseemly words, etc., vagrancy; and assault and hinder police, then the public order offences total 96.1 per cent of all charges laid against Aboriginal adults' (ibid.:199). In 1981, the level of detention in Brewarrina and Walgett was 51 per cent of all Aboriginal detentions in NSW, even higher than in 1986. The NSW Anti-Discriminisation Board (ADB) study of street offences (1982) revealed that convictions rates in the Far West were the highest in the entire State (Cunneen and Robb 1987:239).

Despite the fact that we are not dealing with dangerous criminal offences or serious property crime, the Far West towns had the highest police/population ratio in NSW in 1982: Brewarrina, 8 police, population, 2,850; Walgett, 26 police, population, 7,600; Bourke, 20 police, population, under 5000 (NSW Anti-Discrimination Board 1982:12, 239). In 1986 the Bourke police presence was 27 for a Shire population of around 4,000 giving a police/population ratio of 1:142 (Carrington 1990:5). The RCIADIC report revealed a similar pattern of policing in 1991: Wilcannia with a population of 1000 of whom 800 were Aboriginal was serviced by 11 police (Wootten 1991:301). The police/population ratio is 1:77 (ibid::301). This compares to a State-wide police population ratio of 1:432 (Carrington 1990:5). In the urban, middle class suburb of Chatswood, by contrast, the ratio is 1:926 (ibid:5). What such figures reveal is the high level of surveillance and monitoring exercised in small rural towns. The nature of the offences indicates that a particular type of policing is directed at achieving social control over public space. These offences allow for high levels of discretionary power to be exercised by police. Police are required to intervene in routine and direct engagements with public and personal spheres of conduct, behaviour or demeanour.

The relatively low status of offences seems somewhat at odds with the high level of deployment of police. Yet the fear expressed by police of an Aboriginal insurrection reveals something of a deeper and more complex picture of interaction between Aborigines and police than the figures alone show. The anecdotal evidence in the Police Intelligence Reports suggests that the act of policing is not simply about issues of law and order. The struggle to control social space is more than the containment of those who exist outside normative categories and who must be made to uphold the law through a show of force. It is [nothing less than] the policing of cultural and political borderlands which can account for the emotional energy expended on the struggles for control of public space.

\section{THE FAR WEST AS CONTESTED SPACE}

In the findings of the RCIADIC there emerges a social world of ambivalence and ill defined borders. The individual death reports provide a disturbing picture of the desperate existence of many Aborigines who live in the Australian society. ${ }^{3}$ The asymmetrical power relations 
are writ large in the prevailing conditions of social existence, health and life expectancy and a highly disproportionate rate of criminalisation, which clearly demarcate the social and material conditions of the powerful and the powerless. Yet, in the testimony found in the RCIADIC reports, we glimpse something of the equivocation and anxiety that underpins the exercise of power. What emerges is an ambivalent, but enduring engagement with alterity. That is, the alterity of Aboriginal social life is not confidently and routinely suppressed and dominated. Rather than certitude there is anxiety and instability in the social demarcation between Aboriginal and Gubbah (white) existence. The interplay between the social reality and the moral imagination is an arena of moral ambivalence and fear. In the imaginative landscape of policing in the Far West, the sovereign authority of the state seems vulnerable to challenge.

In particular, the police testimony reveals the uncanny experience of those who exercise power, authority and agency, and, yet, seemingly experience their social world as if they have lost the decisiveness to act. They seem to inhabit a world that threatens to overwhelm them. The fact that the testimony emerges from an adversarial juridical system must be taken into account. The evidence accumulated in the RCIADIC reports and found expression in the 'law and order' campaigns that dominated the politics of major areas of rural NSW in the mid-1980s. In both the political and legal arenas, the meanings, norms and behaviours are never transparent, and social interactions between Aborigines and non-Aborigines lend themselves to multiple interpretations. For the inhabitants of the Far West, there exists a more complex social map of spatial and psychic forces.

The politics and proceedings of the RCIADIC dominated Aboriginal and non-Aboriginal relations in the $1980 \mathrm{~s}$. The RCIADIC was shaped by a commitment to equal rights and the bringing to account of institutional forms of discrimination, which began in the $1960 \mathrm{~s}$ (see below). The granting of equal rights and a rejection of racism, however, produced in part a more radical contestation of the existing political and social order. Indeed, in the following decade, the issues surrounding indigenous rights, initiated in the High Court decisions on Mabo (1992) and Wik (1996), have dominated the political agendas of the 1990s which, in turn, have generated their own debates and varying levels of contestation. Paradoxically, the legislative change granting equal rights did not resolve the Aboriginal "problem'. Increasingly, Aboriginal people have come to see themselves as indigenous subjects in their own right and not simply the objects of assimilation to be acted for or acted upon. Indeed, the latter decades of the 20th century ushered in a period of indeterminate relations, when all that had previously constituted Aboriginality no longer remained a stable and predictable site of knowledge.

The following is an ethnographic account of some of the disquieting and violent aspects of these relations. In the 1980s, the Far West appeared as a flashpoint for racial tension and conflicts between Aboriginal people and the police and a number of direct confrontations occurred. The narratives of this aspect of these relations are found in the RCIADIC reports and in the research materials from the Bourke 'riot' (Cunneen and Robb 1987:182, Cowlishaw 1994) (see below) and the Brewarrina riot trial. ${ }^{+}$The latter riot occurred on the night of the funeral of Lloyd Boney which was held a week after he had died in police custody. His death was later the subject of the RCIADIC report discussed above. There was a violent confrontation with Aborigines when the police moved in to break up the wake. Seventeen Aboriginal people were subsequently charged with offences which were heard in the 'Brewarrina 17' Riot Trials in Bathurst in 1991. In the violent confrontation and in the trials of those charged with responsibility for the riot, the Far West is represented as a violent and unstable world. The 'riot' received national media coverage on television and in the major city newspapers. ${ }^{6}$ The representations of the 'riot' were framed in terms of allegedly drunken Aborigines attacking police.

The Far West is perhaps better understood in Pratt's (1992) terms as a 'contact zone', as 'social spaces where disparate cultures meet, clash, grapple with each other often in high- 
ly asymmetrical relations of domination and subordination' (1992:4). It is a contested space because the peculiar conditions of history dominate the life of a particular people. Such contested terrain is not spatially determined by physical geography, but created as part of the racial, historical and cultural geography of the modern settler state formation. For Pratt (1992) 'contact zones' emphasise relations between the two groups not in terms of their separateness, 'but in terms of their co-presence, interlocking understandings and practices' (1992:7). Contact zones exist on the borders and margins of society. Yet, as Stallybrass and White have pointed out, it is in these unstable zones that the "most powerful symbolic repertoires are found' (1995:20). Citing Babcock, they assert that 'what is socially peripheral is often symbolically central' (1978:32). It is these marginal spaces where separateness is replaced by co-presence that the raw edges of these symbolic repertoires are played out and 'out of all proportion to their actual significance' (1995:20).

\section{REVELATIONS IN THE BREWARRINA RIOT TRIAL}

The Far West is a cultural borderland, not just any borderland, but a historically specific one. It is conspicuous for the numerically significant Aboriginal populations that continue to live in the region and their racially and culturally defined distinctiveness. Co-presence is not marginal, but central as a mode of social existence. It is achieved at a price, which belies its social meaning in liberal policy as a gesture of tolerance. Perhaps, the price of copresence in the Far West can be found in a dramatic exchange during the Brewarrina 17 Riot Trial. The exchange began between Judge Nash and defence counsel, Cavanagh. The Judge, who, as a resident solicitor had practised law in the Far West (Bourke and Brewarrina) for some 12 years, made the following statement during the sentencing of the defendants:

The court in Bourke at the time, the late 1950s and 1960s, the court sat only once per month and it was largely white people who were accused. 1 don't know what happened to change it, but it changed in the 1970s.

Provoked by the defence counsel's assertions of 'white prejudice' and in particular the 'concerns of the Aboriginal people regarding police', the Judge continued:

That is the kind of statement indicating that things could have changed at least since the mid-1960s anyway. We would never have had anything said like that in those days. Things have completely changed. Why? I'd love to know. The housing conditions for Aboriginal people were abominable, but in terms of personal relations, people got on well... I have great difficulty following why, if conditions have improved, that race relations have got worse (3rd May, 1991).

At this point one of the defendants stood up, challenged and rejected the Judge's reminiscences with the simple statement that this was the same time that his father had to have a 'dog tag' (exemption certificate) to drink alcohol.

The exchange offers a template of the great divide that orders contemporary social relations and interactions in the Far West. Judge Nash's nostalgia for the 1950s and 1960s echoes a concern for a more stable, if not entirely 'virtuous' past that has undergone decisive change for the worse. Ideal community relations could exist despite the unfortunate material conditions under which Aboriginal people lived. Thus, this 'other time' is an object of nostalgia, where the categorical rules and the well-regulated demarcations of social life were understood and observed as opposed to the present which is deprived of the security of recognised rules and known consequences. But for Aboriginal people this 'other time' was a source of rebuke and contestation; a past remembered as grounded in the rules of segrega- 
tion and acts of exclusion in a racially ordered world. The challenge to the Judge's historical reminiscences ended abruptly in an act of absolutist authority, as the Judge responded with a threat of exclusion, reminiscent of the past, by telling the defendant that another outburst in his court and he would be removed back to the cells.

The period the Judge identifies is significant to the change in status of Aborigines. Racially discriminatory legislation was progressively repealed and social and civil rights formally extended to Aboriginal people. The discriminatory legislation revoked included: segregated schooling (1952), social security restrictions on unemployment benefits, maternity allowances, family allowances, sickness benefits (1957), government pensions (1959) and the special legal provisions relating to vagrancy, consorting and the ban on drinking alcohol (1963). These legislative shifts underpinned fundamental and decisive changes in social relations between Aborigines and the local community. Judge Nash assumed that a 'friendly amalgamation' should have been achieved through legislative change granting equal rights. Manifestly, this did not happen. What has emerged instead is an heterogeneous space where there is a contest over the meanings of racism, of equality, of history and colonialism and its aftermath. In the courtroom setting, the boundary between dominant and subordinate remained clearly demarcated. In the contested space of the Far West however, neither a clear-cut social profile of hierarchical order nor the privileged control of social space continued to exist. Indeed, the hierarchical principles that doubled to encode cultural/racial difference were now subject to challenge.

Stallybrass and Whites' notion of the 'grotesque of boundary phenomena' (1995) seems useful here. The social and symbolic domains of the heterogeneous space of the carnival, the fairground and the marketplace are their principal interest. They seek to interrogate 'the boundaries and hierarchies which connect, by separation, classes and discourses' (1995:194). The primary concern is with processes of the cultural demarcation and symbolic differentiation along class lines. What is given particular focus are the instabilities at the boundary crossovers, where grotesque figures are produced out of the very drive to demarcate boundaries. For Stallybrass and White, there are two distinct kinds of the production of the 'grotesque'.

The first is the simple production of the self/other in relation to the self-defining group. In the period Judge Nash refers to, the political exercise of social and cultural boundary demarcation was expressed in the Far West through formal policies of discrimination and repression and practices of segregation and exclusion. The construction of the colonised, the inferior natives, did not simply legitimate domination; racial categorisation was essential to demarcation and boundary maintenance. Yet, while the allegedly diminished capacity and responsibility of the 'other' resulted in the denial of rights, it was not essentially a source of threat. The threat of the 'grotesque other' was carried in the fear of pollution and contamination. The spectre of the 'grotesque other' animated the segregations into separate housing on the 'mission', separate facilities at the local hospital and the front row at the cinema, and it denied access to public facilities, the local school and the swimming pool. In this production of the grotesque, the other is not simply the negation of the self, but a source of contagion, a fear of bodily inundation. The act of exclusion is constitutive of social identity.

The second form, Stallybrass and White argue, is found in context of 'hybridisation or inmixing, in which the self and the other are conceived to be enmeshed in an inconclusive, heterogeneous, dangerously unstable zone' (1995:192-193). In this context, a no man's land emerges where pre-existing boundaries become permeable, socially stable zones become unfixed and fractured along internal lines of uncertainty. We deal here with the historical and social conditions, which produce unstable identities, unstable in their inconclusiveness. What emerges is the capacity for slippage from one form to another or to simultaneously embody both. I do not seek to reify 'hybridity and inmixing' as a necessary principle of uncertainty, but to stress the importance of the social and historical context of change and 
repression as the condition of uncertainty which creates contested space. For Stallybrass and White, it is the drive for a singular collectivity that underpins the production of the grotesque (1995:194).

The point to be drawn from Stallybrass and White is their recognition of the significance of the pairing of the inexorable fear of the illegible and the unpredictable of marginal spaces, with the panopticon principle of governance. The primacy and historical ascendency of the panopticon principle of transparency and pedagogy identified by Foucault (1980, 1984, 1987), is consistent with the forms of governance in the Far West. The testimony from the Far West, however, provides us with evidence of a different story through which the limits of the politics of transparency can be explored. As Vidler has argued, it is the very insistence upon the 'operation of power through transparency', which Foucault has made us so familiar with, that ultimately 'resists exploration of the pairing of transparency and obscurity' as 'essential for power to operate' (1992:172). The logic of the politics of transparency is driven by attempts to eradicate the illegibility of peoples, individuals and of social things. The commitment to render legible the spectres of the other is to explain and to manage them. For Vidler, there is an 'intimate pairing of the two' rather than replacement of one by the other (1992:172). In other words, the calculus of government rationalities does not erase the symbolic and ideological associations that fill the cultural space between indigenous and non-indigenous peoples in the Far West.

At one level, the circumstances are not purely local and contingent. Due to the lack of transparency of all its subjects, the cultural borderlands in liberal state formations are often treated as anomalous and/or as a locus of anxiety. As Iris Young points out, in liberal social ontologies, the constitutions of community and of the individual share a common logic. For Young, "each entails a denial of difference and a desire to bring multiplicity and heterogeneity into unity' (1990:228-229). The denial of difference works at two levels:

Liberal individualism denies difference by positing the self as a solid self-sufficient unity, not defined by anyone or anything other than oneself. Its formalistic ethic of rights also denies difference by bringing separated individuals under a common measure of rights. Proponents of community, on the other hand, deny difference by positing fusion rather than separation as a social ideal. They conceive the social subject as a relation of unity and mutuality composed by identification and symmetry amongst individuals within a totality (1990:229).

On the cultural borderlands, it is precisely 'the self as a solid self-sufficient unity' and a 'relation of mutuality and unity' that is absent. It is specifically the lack of transparency of its subjects, which renders the 'community' on the cultural borderlands anomalous, as not fitting into classificatory systems and rendering the judicial system as a site of cultural contestation.

The construction of a racial criminality in the Far West region, for example, began in the early 1980 s and took on the meaning of a particular transgressive threat. It culminated in a law and order campaign run by the conservative political parties for the State elections in NSW in 1988. The 'law and order campaign', as it was called, positioned non-Aborigines as victims of 'Aboriginal criminality' waged against them. ${ }^{7}$ The relationship between meaning and events is not bound up in the truth or falsity of the events, but between their symbolic functions and the reactions they engender. In the law and order campaign, the issue of social conflict between Aborigines and non-Aborigines was displaced from the politics of racial condemnation and converted into a social cause for more efficient and effective policing. The threat is not located in themes of contamination, but disorder borne out of moral weakness and a loss of control. The dichotomy of self/community and Other remains, but the latter has transformed into a transgressive threat: that is, the threat of being subsumed within this criminal form of social order. The 'other' exists within rather than beyond the 
self/community. The 'Aboriginal other' is treated as having the formal rights of the citizen, but is regarded as lacking the requisite sensibility. Aboriginal modernity is reduced to a hollow mimicry of the liberal subject: a copy that menaces the existence of the original. The carefully divided world of the past is threatened by the amorphous mix of the present.

The state of siege rests upon an agonistic mode of authority that emerges from the boundaries constructed of self/other. Its discriminatory effects are evident in the policing practices of the Far West and in the racial stereotypes of an Aboriginal criminality that remained central to the campaign. ${ }^{8}$ But, importantly, it is not simply Aborigines who are condemned, it is the policies and practices of the State itself, condemned as ill conceived, misinformed, naïve and 'out of touch' with the realities of policing the borderlands. In these episodic moments of moral panic, such as the law and order campaign, it is both the centre and the margins that are demonised by different groups. As political positions become dichotomised, there is no argument about who are the demons.

On the other side of the divide, the conditions of ambivalence are inverted, a kind of mirror image negative. One of the few sources of information of an Aboriginal perspective on the Far West 'riots' is found in an interview conducted by Cunneen and Robb with a long standing Aboriginal resident of Bourke after one of the Bourke 'riots'. ${ }^{9}$ The 'riot' began in front of a hotel and led to a confrontation between Aborigines and police on the streets (Cunneen and Robb 1987:182). An estimated 50 to 80 Aborigines, mostly youth, were involved in the melee. Bottles were thrown and some police injured. The catalyst for the melee involved the perceived lenient treatment by police of a non-Aboriginal man who had allegedly reversed his car over the head of an Aboriginal youth the day before. It had been rumoured that 'the driver had only been charged with negligent driving and released' (ibid.:181). The substance of the interview makes clear the police are regarded as applying the law in an arbitrary and highly partial manner. It is the common experience of discrimination by local state bodies that Aborigines share collectively. The experience of sharing the same space as liberal subjects slips away. When asked 'what you actually saw of the riot', the long term resident explained:

I just saw something that has festered over many years and it just came to a head. You see it nearly every day. You see the anger, the frustrations in the people and what happened, it just triggered everything off. Its something that's happening its been happening here in Bourke for years... What annoys me about the whole thing is that people tend to look at Aboriginal people. They point the finger at the Aborigines. It's a problem - it's a black and white problem in this town. What I saw of the riots that night I saw people throwing bottles. I see that nearly every Wednesday night (Cunneen and Robb 1987:263).

There is not a denial of complicity in the social situation. Being on the border and being Aboriginal, negotiating a world of opposing ideas and inferiorising knowledges, one cannot escape the burden of race: the luxury of not being angry is not available.

Yet, what is fundamentally important here in the Aboriginal testimony is the assertion of the denial of their rights as liberal subjects. The denial of such rights can be seen, they assert, in the differential treatment of Aboriginal people before the law, which is made explicit through localised policing practices. In this particular case, the 'lenient treatment' given to the man in custody is contrasted with the treatment given to the Aboriginal people of Bourke who had organised a demonstration on the day of the court case. Those who participated were confronted with a show of force from the paramilitary trained TRG, which was deployed in the town. Despite these security precautions, it was deemed unsafe for the accused to be lead to the courtroom (ibid.:265). As the same woman stated, the 'man was kept hidden and the police wouldn't communicate with the people' (ibid.:265). What the police are asserting by refusing to allow the appearance of the accused, is that the Aboriginal 
demonstration is not only potentially violent, but carries within it the seeds of a 'lynch mob' mentality. The Aborigine as grotesque other emerges as an imagined possibility in this contested space. According to the Bourke woman:

All the Aboriginal people wanted to see that man brought across to the court. That's all they wanted to see. But they wouldn't do that. The Aboriginal people were here to see the man being charged. And this is where the anger kept building up all the time. But yet they brought two Aboriginal boys handcuffed with about ten policemen surrounding these two kids. They brought the riot squad from Sydney and mingled with the crowd. But all the people wanted, they weren't going to smash the town up anymore, they wanted to see that man brought over. To see justice being done (ibid.:265).

The Aboriginal people were assembled to see justice done, to witness the public expression of justice at the local level. In effect, they were simultaneously countenancing and placing under critical scrutiny the symbolic status of the law as operating in terms of the equality of all citizens. Nevertheless, the precautions taken by police simply reaffirmed for this woman the historical circumstance that there exists 'one law for the black and one law for the whites' (ibid.:265). In effect, Aboriginal people's rights are said to exist, but in the absence of any material connection to policing practices. Rights remain segregated and hierarchically ordered in their implementation. ${ }^{10}$

\section{RACIAL SUBJECTS}

Racism creates its subjects on both sides of the divide. In the following, I seek to explore something of the experience and interpretation of the cultural borderlands found in the police evidence of negotiating a world of multiple meaning and opposing ideas and knowledges. Again I use police testimony from the RCIADIC, as well as evidence given at the Brewarrina riot trial as sources. The police are the most visible face of State authority, who must be willing and able to uphold the law, but, perhaps, more importantly, to seek and to win compliance to order. There emerges a strong emphasis on a world of contingency and the necessity of a contingent jurisprudence. The metaphor of centre/margins delegitimates the dictates of the centre as bureaucratically bounded, ill conceived, misinformed and 'out of touch' with the realities of policing the borders of uncertainty. The unifying and unrelativised authority of police sovereignty over the street is experienced as one of confrontation driven by the dictates of alternate sovereignties. The world of the Far West is constituted in terms of fear and provocation and, alternatively, contempt and derision. The police call upon the specificities of conditions in the Far West to free themselves from the dictates of the rules of policing. The contingent conditions require the exercise of more discretionary powers than are usually accepted in policing activities.

The everyday interactions of police and Aborigines can be contrasted with the characterisations that emerge from the politically staged performances of the courts and Royal Commissions. The unanticipated ruptures of riots and Aboriginal deaths in custody are most effectively contained by a judicial focus on the State apparatuses, which seeks out its own abuses of power and identifies them as aberrations. When the Royal Commission Report brought down its findings on the death of Lloyd James Boney in police custody, the Brewarrina lock-up where Lloyd Boney died had already been pulled down. As if in an act of cleansing, the offending structure was removed. Its erasure from the physical landscape after Lloyd Boney's death, removes the rupture at its site. Aborigines are no longer held in custody in Brewarrina for more than 2 hours before they are driven to Bourke lock up and held there. Disorder is dispatched in the dispatch of a building. Order is restored in the next town along the road. Yet, an earlier report from the NSW ADB (1982) had previously stated 
that the conditions in the lock-up 'are clearly unsuitable for any person, let alone one who has committed no legal wrong and is in need of care'. This referred to the practice of locking up intoxicated persons, despite the decriminalising of public drunkenness as an offence in 1979.

As an act of cleansing, erasure has limited efficacy. The either/or logic of its absolutist authority does not hold in the everyday world of policing. In the continuing attempts to maintain comprehensive control, police find it necessary to bend the rules. There is a continued resort to the exercise of arbitrary power and personal discretion, to bending rules and procedures to facilitate control of the population. Thus, the subterranean domain of policing is constructed. This occurs in greater and lesser forms. Under the Offences in Public Places Act (1979) and the Intoxicated Persons Act (1979) being drunk in a public place was no longer deemed a criminal offence. However, an intoxicated person could be held for 8 hours in a proclaimed place. In many country centres no civilian proclaimed place was created and, hence, as in Wilcannia, the police station doubled as a proclaimed place. Thus, despite the 'decriminalisation' of drunkenness, Aborigines continued to be locked up in the police cells as a result of being drunk. The experiences of arrest changed little for many Aborigines.

Under the Police Commissioner's instructions (Circular 86/157, August, 1986), it was stipulated that such detained persons in police stations 'should be kept to a minimum' and 'where there is no civilian proclaimed place available... (should) be taken home' (cited in Wilson 1988:32). Yet, in late 1986 and through the six month period following, there appeared no attempt to comply with such instructions. The point that Wilson makes is that such a high rate of detention for intoxication is in direct violation of the Commissioner of Police's instructions.

The situation is further complicated by the apparent conflict between policing practices in the Far West and the application of the procedures for the Intoxicated Persons Act, (1979). The fact that rural police stations remained unsupervised overnight meant that intoxicated Aboriginal persons were often detained in excess of the maximum eight hours detention period. Again, in the case of Wilcannia, the Royal Commissioner found that in the six month period between January, 1987 and June, 1987, of the 150 Aboriginal people detained, 109 were held illegally for longer than the prescribed maximum period (Wootten 1991:51). Evidence from Cunneen and Robb (1987) and the findings of the RCIADIC in NSW, suggest that such 'discretionary practices' which breached formal rules and procedures proved commonplace. What is equally important is that the 'breaches' worked quite pointedly to the disadvantage of Aborigines.

The Royal Commissioner's reports were highly critical of police actions and conduct in the region. In the case of Mark Quayle who died in the Wilcannia police cells, he was scathing in his assessment. The connection between what he called the 'massive and often illegal locking up of Aboriginal people' and the complacency with which Mark Quayle was removed from hospital care to a police cell is directly linked to such often illegal but routinised policing practices in Wilcannia. The Commissioner found the two officers acted without legal or moral justification' (1991c:5) and that the 'shocking and callous disregard' for an Aborigine had resulted in his death:

The police took Mark to the police station. Except that they did not fingerprint him, they treated him like a prisoner, removing his property and checking whether there were any outstanding warrants, which there were none (1991c:5).

These practices, as the ADB had revealed in 1982, were routinely applied to Aborigines taken into custody for drunkenness, despite decriminalisation. What is particularly important in this case is that Mark Quayle had not been drinking and had gone to the hospital as a patient to receive treatment, but was, nevertheless, to all intents and purposes processed as if 
a criminal. His death was not the result of a rupture of normal practice, but the accumulation of systematic breaches, which had become routinised as everyday practice.

Such routinised breaches were not standardised. Bending the rules provides the basis for discretion and discriminating behaviour on the part of police, which symbolically encode what is locally deemed as necessarily appropriate for Aborigines and other locals. To apply them indiscriminately runs the risk of rendering symbolic demarcations meaningless. Acts of reaffirmation of identity must also be made. The Commissioner found a marked discrepancy in the treatment of a drunken and abusive, but prominent white citizen, and those handed out generally to Aborigines. In one particular case, the Commissioner recorded the procedures revolving around the removal by the police sergeant of a citizen who, drunk and speaking loudly, made abusive accusations in the hotel at closing time aimed at the Aboriginal clientele: 'these black cunts have fucked this town' (1991c:120), he stated. As the police sergeant removed him, he continued his drunken abuse of Aborigines. When taken to the police station, he demanded to ring the Regional Commander. Although not followed up by the citizen, the police officer agreed to the request. Ultimately, the sergeant used his discretion to contact the man's son, who arrived at the station to calm his father down and finally take him home. No police action was taken. This sensible exercise of restraint and discretion, as the Commissioner pointed out, would not be extended to Aboriginal citizens and demonstrates the hollowness of the formal impartiality of the law (1991c:120). Difference is reaffirmed in the capacity to discriminate between civilised behaviours when policing those associated with the 'self' and against the grotesque other. Acts of differentiation can be acts of redemption, redeeming the category of 'white' to civilisation from the disordered realm of Aboriginality.

The police act as a symbolic barometer of authority and control as the upholders of the sovereign power of the State over this contested space. They police the borders of uncertainty and manage social ambivalence. It is the police who are called upon as the arbiters or as the ultimate sanction of authority. The lonely death of Mark Quayle in Wilcannia, provides ample evidence of the dynamics of power in this arena of cultural contestation. Mark Quayle died in the early hours of 24th June, 1987, alone in a cell at Wilcannia Police station (1991c:1). Earlier that morning, at 2.10 a.m., he had been brought by relatives to the Wilcannia Hospital. Mark had awoken them earlier telling them he was starting to go into the 'horrors' (1991c:20). He was disoriented and hallucinating as a result of alcohol withdrawal, of what is colloquially called, 'being in the dings' or 'the horrors'. For Mark, 'being in the dings' meant that 'he was shaking' and kept on saying 'he was cold, he was seeing things... and could not sleep because he was hearing things' (1991c:20). In medical discourse, the patient could be suffering delirium or some acute psychiatric illness, experiencing schizoid episodes. Local Aborigine, 'Badger' Bates, placed his symptoms in an Aboriginal frame of reference, as he put it, "Aborigines in the area believed in and were afraid of spirits, in particular of Dinagoollies or "clever men' who punished wrong doers' (1991c:54). This is why he believed Mark, whom he knew well, 'slept with the light on, because he was afraid of the dark, a fear related to a traditional belief in spirits' (ibid.). This is no place for a discussion of such a culturally nuanced assessment of Mark's condition in this medical setting. On the cultural borderlands, being dispossessed and marginalised also means your cultural understandings and social needs are cast aside and ignored. In the working of the institutional space of the hospital, they are simply opaque and erased.

At the hospital, despite the presence of a qualified nurse and a wardsmaid and telephone conversations with the hospital matron and a medical doctor, Mark was neither placed under observation, diagnosed nor treated. Three years earlier, in September, 1984, friends had brought him to the hospital with the same symptoms and on admission he was treated, 'sedated with a hermineurin regime' and discharged in five days. On this second occasion, confused and wandering about he disappeared out of the hospital and the wards- 
maid's response was to comment that he had 'gone walkabout' (Wootten 1991c:20) and to call the police. 'Walkabout' exists as a national trope often deployed to explain Aboriginal 'unpredictability', the evidence of an unstable interiority. Aborigines have historically been depicted as going on 'walkabout'. Even Evonne Goolagong (Cawley), a celebrated Aboriginal tennis player, is said to have lost many games, because she went on 'walkabout' in crucial matches. Racial codes explained her inconsistency allowing her lapses to be put down to her Aboriginal identity. This well-worn stereotype takes the place of more culturally nuanced understanding.

The stereotype was apt though and to the point in terms of the medical staff's response. It was Mark Quayle's 'unpredictability', not his medical condition that arrested the concern of the medical staff. As the Commissioner pointed out, there were three concerns that dominated, 1) the patients own safety in as much as he may fall in the river; 2) the absence of a place to confine the patient and 3) the risk to other patients, including two children, due to his unpredictability (Wootten 1991c:36). The image of the unrestrained grotesque is evident in all of these concerns. As the Commissioner pointed out though, none of these concerns included the treatment of the patient's condition (ibid.:36). Assessment is made in terms of a calculus of risk based upon Aboriginal unpredictability.

The process of normalisation, as Carrington (1991) has shown, reveals much of Mark Quayle's progress from a medical setting to a cell, understood in terms of the 'drunken and disruptive Aborigine'. Foucault's characterisation of modern power has made us familiar with such normalising forms of governance. Yet missing from his account is the pairing of the politics of transparency and the inexorable fear of the unpredictable other. The calculus of risk used in processing Mark Quayle is based upon probability, a probability measured in terms of the shadowy grotesque figure of the Aboriginal other. This fantasised construction of the grotesque other requires an experiential rendering of the social.

The death of Mark Quayle provides a localised version of the operation of power through the politics of transparency. Racial discourses do render the Aboriginal other knowable. Power is exercised through racial discourses to explain Mark's condition in a medical setting. At the Commission hearing, the matron affirmed that 'being locked up in a cell was the only way Mark could be stopped from wandering around'. Unpredictability could be contained in a cell. Furthermore, as the matron stated, 'patients sleeping in cells happens to lots of other (Aboriginal) boys' (Wootten 1991c:27). Defending this practice, she stated that 'most people that were uncontrollable in the hospital were under the influence of alcohol and the majority of these people were Aboriginal' (ibid.:28). As an Aborigine, Mark Quayle's unpredictability was rendered predictable (knowable) in this racial discourse, as he was presumed to be affected by alcohol and disruptive. Similarly, as the Doctor stated, "he understood that the patient was in (police) custody at the time of the telephone call' (ibid.:34), when he agreed that it would be best if Mark was placed in a cell. The Doctor assumed the Sister had all the 'relevant information' (ibid.:34) and the Sister who had access to the Outpatient and Inpatient records, "had not read them' (ibid.:35)." The individualising strategies of medical treatment are replaced by racial typifications. Mark, who was already in the paddy wagon throughout the discussions (ibid.:4), was removed from the hospital and placed in an unlit cell, where he had no access to the lights. The routinisation of breaches of everyday practices operated across and between state institutions as a norm not as an aberration. Confinement in a cell removes the disorder, but, more importantly restores order, for a time, on the cultural borderlands.

Yet, as the Commissioner pointed out, such breaches revealed a harder edge than simply complacency and neglect. Contempt and derision surface regularly from behind the thin veil of complacency and neglect. This is revealed in the callous disregard Mark Quayle's family received after his death. In the evidence of the police officer, who took Mark into custody, there is an example of the perverse logic that surfaced as part of the explanation of his death. The fact that Mark Quayle was brought to the hospital for treatment by his rela- 
tives, became evidence that 'his family didn't want him because they brought him to the hospital and left him' (ibid:36). Later, this was cited as evidence that Mark's family had 'dumped him' at the hospital, a suggestion the Commissioner described as a 'cruel lie' (ibid.:37). The report into Mark's death sheds light on the productions of knowledge practised in the Far West that seek advantage at the expense of the victim.

Furthermore, in another example of contempt, conventions associated with dealing with the deceased were cast aside. Instead, the Commissioner recorded:

In a revolting display of inhumanity, Constable Coombes stopped an ambulance, containing Mark's body in a bag, in a main street in Wilcannia and called on Mark's brothers to get in, climb along their brother's body to his head and identify him, on the implied, if not expressed, threat that if they did not do so the body would be taken to their mother's house for identification (ibid.:7).

As Marcus suggests, at the margins of culture, there is no civilisation (1991:129). In Taussig's terms this is 'low intensity conflict' affirmed in its 'leading characteristic...to blur accustomed realities and boundaries and keep them blurred' (1989:11). Aboriginal status as citizen recedes in the face of such abhorrent acts, which afford them neither the sympathy nor the dignity that would be expected by other citizens. The 'breach' is even more telling given that in the case of wilful or accidental loss of life, the difficult role of informing the next of kin often falls to police as part of their training and duties to the public.

\section{CONTINGENT JURISPRUDENCE}

There was more extreme evidence that the practice of a contingent jurisprudence is widespread. There was falsification of evidence and, hence, the violation of the criminal justice process itself by police officers. The Commission's inquiry into the death of Lloyd Boney supported the Coroner's previous findings that the police officers had lied under oath, had fabricated evidence about the events and had unlawfully denied bail to the victim (Wootten, 1991b:55-62). The Commission found evidence of police officers lying under oath in other N.S.W. cases of Edward Murray, Bruce Leslie and Lawrence Kearney (SMH, 11/5/91). In his final report, Commissioner Wootten found that 'negligence, lack of care and/or breach of instructions' by custodial officers 'played an important role in the circumstances leading to 13 of the 18 deaths' (1991a:63). Criminal or disciplinary action was recommended in relation to seven deaths (ibid.:83). Thus it is in negligence and in breaches, that the sources of these ruptures of proper procedures are found. The Commission seeks to regain order, mend the breaches, and regain the certainties, which will re-affirm the order of the State. The notion of the State ordering the disorder slips out of view. It is as if the violation of procedures and practices is not part of the potential violence structuring the everyday, but an aberration. For the Commission, it is the ruptures, the unanticipated event that captures attention.

Those policing the cultural borderlands have their own theory. As noted above, the centre/margin metaphor shapes its meaning. They assert that there is a state of emergency that explains the arbitrariness of order and procedure. Superintendent Harding, the officer in charge of the investigation into the final death investigated by the RCIADIC, that of David Gundy in Sydney, made no pretence. ${ }^{12}$ When asked if the police had acted reasonably, he replied that 'I know why they did these things and to be perfectly frank, I have done them myself and understand the philosophy behind them' (1991:153). And when asked about how seriously he was concerned with the issue of the actual lawfulness of the raid he responded by saying, 'In this sterile atmosphere (the Royal Commission hearings) most certainly, but out in the field where its happening, no' (1991:153). There is no distancing-effect on the hard edge of policing where uncertainty is the only constant and must be countered. 
In this exchange, there is a falling out within the order of the State. Attention paid to the State's abuses of power is counteracted by the assertion that arbitrariness is needed to control its own state of siege.

Contingency can operate, paradoxically, by fixing firm boundaries, by closing ranks, by producing 'all or nothing' categories of guilty/innocent. Commissioner Wootten has stated that he became 'very conscious of the existence of a 'police culture' in which 'there is a very great blindness... to the problems of police investigating police, and a very great reluctance to acknowledge the possibility of wrong doing by police'. The standard procedure of inquiry is for the police to have a central role in investigating police. Wootten has criticised other police investigations into Aboriginal deaths in custody for their haste in exonerating fellow police officers. In the Report of the Inquiry into the Death of Lloyd James Boney, Wootten concluded that the investigating officer 'at no stage subjected police conduct to any real scrutiny, or pursued with any enthusiasm any evidence which might have contradicted police' (1991b:124). Indeed, the Inspector had only been in town overnight and interviewed one officer before he told the media 'he had found no suggestion at all of foul play in any sense' (ibid.:124). The Inspector was sent back to Brewarrina to assist police to investigate and charge Aborigines involved in a melee that followed Lloyd Boney's funeral (ibid.:125). The Inspector, indeed, prevailed as a symbol of continuity in his role at the Brewarrina trial liaising between the Crown Prosecutor and the police witnesses, the principal witnesses in the case against the Aboriginal defendants. There is no position here for being strategically borderless (Taussig 1989:13), for acting as if borders do not exist.

The major focus of the investigation of 'taking life' that concerned the RCIADIC was the role of the police, police actions and procedures. The members of Lloyd Boney's family accused the police of killing him and, according to the Royal Commissioner, it remained 'a very widespread view amongst Aborigines' despite the findings of a coronial inquiry (Wootten 199lb:1). The Commission's report emphasised Aboriginal anger and suspicion of the police in terms of 'the failure to notify the family (and) give them an opportunity ... to see his body before it was removed from Brewarrina' (ibid.:17). The major issue for Lloyd's relatives was the physical impossibility of self-hanging. The attempts of police to explain it failed dismally. The proposition that Lloyd had 'climbed up the door, put his left arm on the door to prop himself up, then tied the sock around the grille' (ibid.:97) could not be achieved by two of the relatives on one occasion and by another on a separate occasion (ibid.:97, 98). The problem is exacerbated by the fact that Lloyd Boney was heavily intoxicated when taken into custody (ibid.:2).

The evidence of the procedures for policing lend themselves to an interpretation that the formal impartiality of the law routinely gives way to more personalised interactions between police and Aborigines. In the series of incidents preceding his death, Lloyd Boney allegedly resisted arrest, injuring the arresting officers before he was subdued. The Royal Commissioner described the incident as a 'bitter struggle'. Aboriginal witnesses alleged that after he was subdued, the police dragged him 'along the ground roughly for up to 50 yards, and that by-standers had yelled out to stop dragging him like a dog' (ibid.:40). The coroner at the inquiry into his death stated that the incident had not been forgotten by any of the parties (ibid.:41). The same police officers were on duty, ${ }^{13}$ arrested and detained Lloyd Boney on the afternoon he died. He had already absconded from custody when picked upon the night before, sut on this afternoon he submitted quietly.

Wilson's (1988) submission to the Royal Commission revealed the potential for policing practices to take on a highly personalised and a deliberately vicious nature. John Quayle, Mark Quayle's brother was arrested for gesturing at police and saying, 'You're all cunts why did you lock my brother up' and was locked in the same cell in which his brother hanged himself. He said that the police officer taunted him saying, 'We're going to lock you in the same cell that your brother took his life. Now, we hope you are not going to do the 
same thing' (Wootten 1991c:119-120). Such words are meant to wound, to damage, as much as any physical blows in these destructive relationships of power and contestation. Personal knowledge serves to vent and satisfy personal animosities.

Policing on the margins is projected as a world continually negotiated against a background of the destabilisation of social order. Lloyd Boney's contestations of, and alternatively, conformity to the sovereign authority of the police had him categorised as 'unpredictable' (1991b:68). Speaking from the centre, the Royal Commissioner concurred, finding the term 'unpredictable' appropriate (ibid.). The Report recounted a number of encounters with police in the period immediately prior to his death. On three of these occasions, he reacted violently or ran, and on two occasions he submitted passively. Lloyd Boney's actions are constructed in terms of the actions of the sovereign individual. When police spoke to him whilst he was involved in an argument with a fellow Aborigine, he allegedly replied in anger, 'it is nothing to do with you cunts, I'll get a fucking gun and shoot both of you.' (ibid.:34). He struggled violently with the police. He was arrested and three months later convicted of 'causing serious alarm and affront and resisting arrest and was fined $\$ 80.00$ on each count' (ibid.:34). Alternatively, in 1982, he was convicted of smashing a glass door at the Royal Hotel. Lloyd explained the incident and apologised, 'I'm sorry constable, you know I don't do things like that." (ibid.:34). Again, in 1983, when convicted of break and enter and the theft of a carton of beer, he allegedly stated, 'I took it Sarge. I had to. I' $m$ crook in the gut and I needed it' (ibid.:32). Lloyd's own personal characteristics and experiences are not registered as significant. Rather, the police consider him unpredictable, erratic and temperamental. He is not seen as someone with kinship obligations or a sense of personal pride seeking just treatment. Police cannot take the alternative sovereign possibilities of the cultural and social world of Aborigines as real.

'Unpredictability' is a discourse of the State that seeks to normalise its subjects. Lloyd Boney's attempts to evade capture are more than acts of individual unpredicability, they act as a form of contestation of sovereignty in an ever-shifting game of cat and mouse. Police sovereignty and the rule of law must insist on being obeyed. No space exists between the exercise of authority and alternate sovereignties, except, perhaps, when constructed in a negative public image of leniency and/or incompetence. Non-compliance, by definition, constructs Lloyd Boney as 'unpredictable'. Indeed, his parole officer considered him as a modern day 'nomad' precisely because he continually evaded the codes, the techniques and procedures of modern state power apparatuses. As the parole officer stated:

Lloyd should never again, due to his nomadic life style, be placed under the supervision of this Service as it only serves as a useless game of 'cat and mouse' (Wootten 1991b:38).

He violates here not only the sovereign power of authority, but also the forms of conditional liberty, which extend and enhance the power of modern State apparatuses to administer life. This is more the frustration of the bureaucrat when due process is wilfully not followed. Adherence is achieved through resort to the ultimate sanction, confinement in a cell. Such an absolutist form of closure is not as readily available in the exigencies of everyday policing. Specific biographical evaluations of individuals by those who police the streets are trusted more. They form the basis of a collective knowledge that circulates between station members. The practice of rotating police between stations, which seeks to eliminate such personalised appraisals, is subverted. In the police photo files at Brewarrina police station, under the heading, 'Additional Information', Lloyd Boney was described as follows,

Has been arrested on numerous occasions... A generally bad egg and should not be trusted. Lives with Gracey who is frequently flogged. Will hit a copper if given the opportunity." (ibid.:107). 
Specific biographical information and evaluation is not supposed to affect the formal impartiality of the law. But here there is no balancing act where violent reactions can be measured off against passive compliance as in the Royal Commission report. In the police assessment, no hint of equivocation about Lloyd Boney's character exists. The verdict of 'unpredictable' found in the Commission report is damning, but too benevolent. In the interests of order, there is no room for slippage between categories. The lines of demarcation are not blurred. For the police in Brewarrina, Lloyd Boney was considered to be thoroughly predictable. He was a 'bad egg', not to be trusted, the embodiment of an Aboriginal violence that pervaded private and public life. A lack of vigilance or restraint may precipitate violence at any time.

The conclusions formed by the Aboriginal community about Lloyd Boney's death cannot be separated from the particular relations, the context of violent confrontations and contestations that formed the social context of Aboriginal/police relations in the $1980 \mathrm{~s}$. Two scenarios were put forward by his relatives to explain his death. In the 'first scenario' put forward by Lloyd's stepfather and the Western Aboriginal Legal Service, he was 'accidentally killed' and the 'faked suicide hanging was staged by police as a cover up' (Wootten 1991b:4). The 'second scenario' asserted that 'police did intentionally kill Lloyd' as a result of the violent relations that existed between the police and Lloyd (ibid.:5). Both explanations emerge from the agonistic and, often, antagonistic relations that exist between Aborigines and police in the Far West. The engagement is an unequal one in which the loss of the 'argument' is visible in the overwhelming representation of Aboriginal people in police custody. The fantasies and anxieties of Aboriginal uprisings, which police harboured, bear little resemblance to the fear and anxiety which pervades the lives of Aboriginal people, in particular, for many, fear of police and police cells. Death in custody is considered a possibility of Aboriginal existence. It is a possibility that no other group in Australia shares.

In the 'second scenario', we see something of the close relationship assumed between personal relations and the escalation of violence. The personalised nature of such contestations play themselves out in male rituals of violence. As Arthur Hooper put it, 'When Lloyd was drinking and anyone tried to grab him "to go to gaol" he would kick his legs, struggle no matter how many of them, he's that kind of boy' (Wootten 1991b:107). The masculine codes of conduct strip the police of their official role and reduce them to the position of 'anyone' to be confronted no matter the odds. Such masculine codes of conduct are given ritual expression in the video evidence of the 'riot' at the trial. The video reveals a confrontation between an Aboriginal male as he challenges a police officer, armed with a baton and shield to fight. In abusive and derogatory language, the man demands the police officer put down his shield and baton and fight like a man, just between the two of them. The police officer refused to even acknowledge the demand.

The challenge was not an arbitrary one. For many Aboriginal people, what precipitated the 'riot' was the entry of the police with batons and shields into the park where the wake for Lloyd Boney was being held. During the ensuing melee in the park, the Aboriginal man had been hit by the police officer with his baton (pers. comm.). The police officer's distinctive dress (he was the only police officer wearing a white shirt and no TRG vest) enabled the Aboriginal man to identify him when he came out to the lit street (pers. comm.). (see plates 1-5) Police action is transformed into personal enmity. Violent personal contest resolves personal enmity. To this Aboriginal man, it was not a matter of law, but a personal conflict to be decided between the two men. Indeed, the policeman was taunted to remove the authority and the trappings of the state he was hiding behind, a challenge to reveal his authentic self. Resolving personal animosities as equivalent individuals through fighting was not common between Aborigines and police, but it was one means available, winner take all, by which issues were resolved unofficially. Some police and Aborigines privilege personal male codes of self worth above those of the State in certain contexts. 

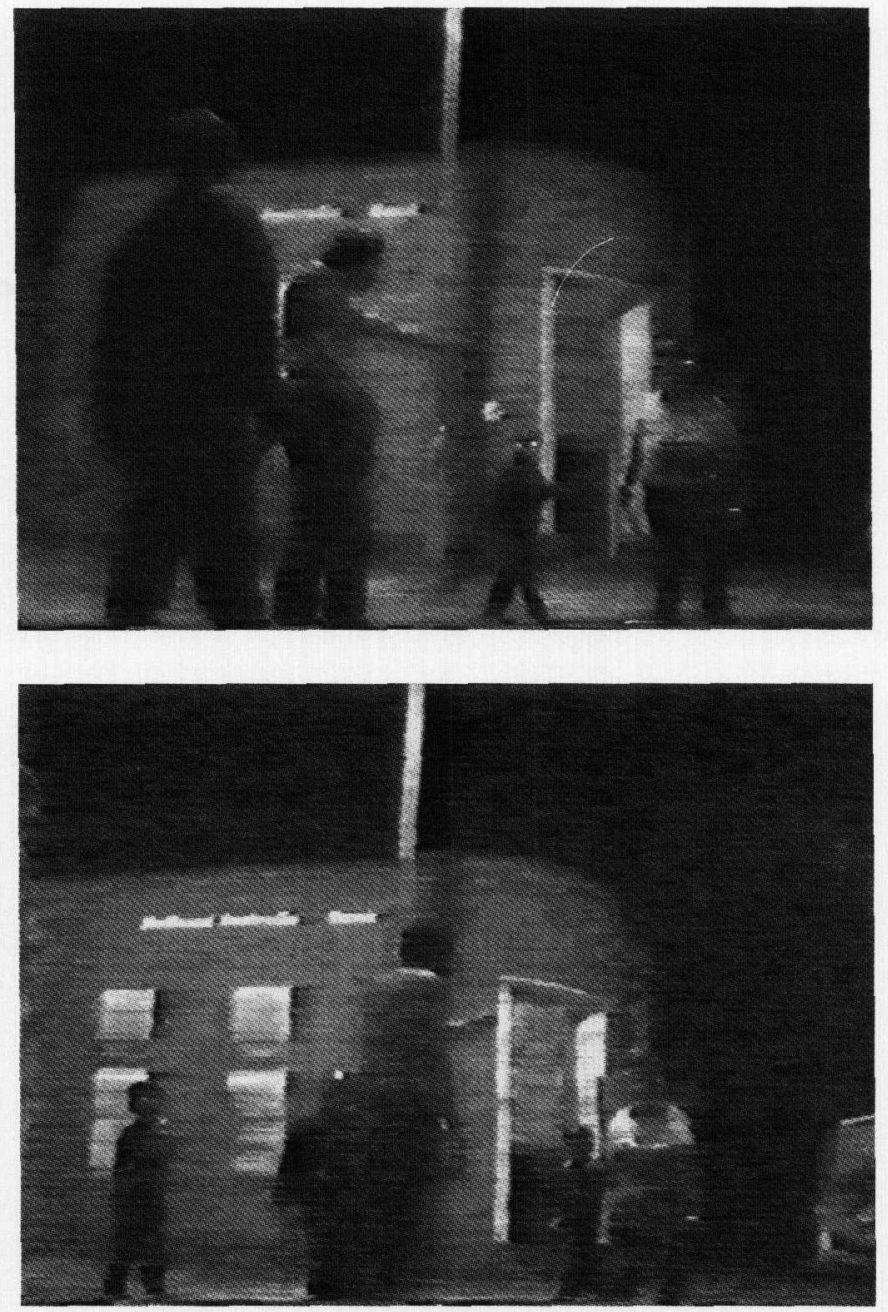

\section{Plates 1-5}

Video frames from $A B C$ footage of Aboriginal man challenging police officer to put down baton and fight man to man. Reproduced with permission from $A B C$

It is in understanding the unofficial ground rules that the asymmetrical power of authority is exercised and sanctioned. That is, another set of codes exists more consistent with the asymmetrical relations of power. A cardinal rule is said to be that if you hit or injure a police officer, then you are in for a 'flogging'. The initial charging of the 'Brewarrina 17' can be understood as a consequence of the logic of avoiding being taken into custody in such circumstances. Once it became common knowledge that two police officers had been taken to hospital after the melee, it became important for Aborigines not to be taken into custody. As one man put it:

There was a so-called riot the night before, police officers got injured, you know they were - we knew that there were police officers in hospital. But we - look, it's hard to explain but it's just a fact of life that in that part of the State, if you're in any way or form - I suppose it happens all over the State, but it happens out there 
Policing Racial Fantasy
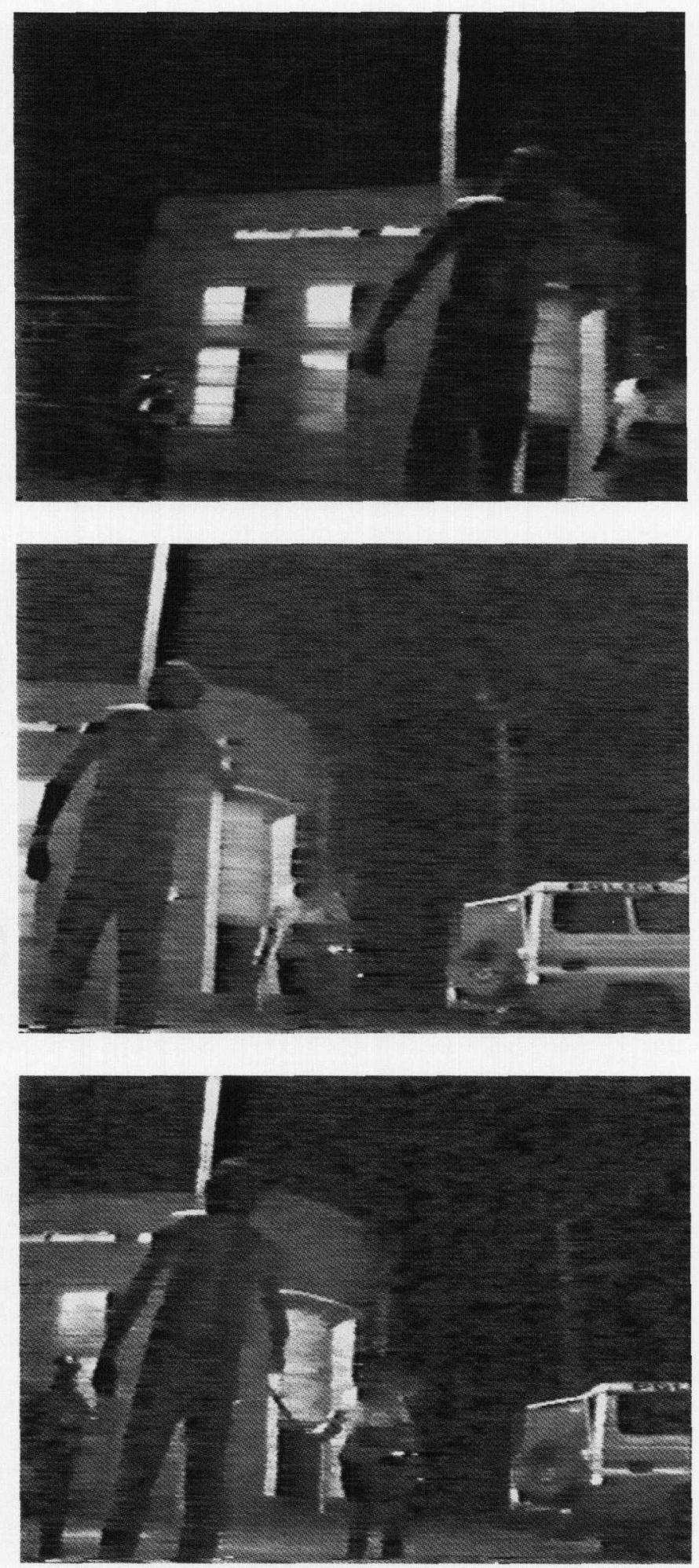
on a regular basis, that if you manhandle a police officer or touch him in any form or .... or assault him, you can expect the same to be dealt back to you, you know what 1 mean? So that's just a common, common practice, that's accepted by both sides, by both parties. So we knew that if we were, had got arrested, if we knew we'd have got arrested that night, what would have happened, they would have escorted us to Dubbo, probably flogged us all the way to Dubbo, because Dubbo is the central base for police operations in the north-west, so we would have been taken to Dubbo and held there for sure. That was our main priority, not to get anyone arrested. (pers. comm.)

In this, the 'main priority' was achieved as no one was arrested on that night or the following day. This particular group made their way out of town to 'Dodge City', where they spent a sleepless night anticipating police retaliation. The conditions to negate police sovereignty are limited and rest upon strategies of evasion.

On the Sunday following the melee, as the town bristled with police reinforcements, it was also known that arrests would be made. The initial arrests of the Brewarrina 17 were the result of the use of an intermediary and negotiation. The use of an intermediary between the police and the Aboriginal community was a common practice. As it was stated to me:

Like when - well the police know that, like, in country towns that if they're after someone well eventually, they know they'll catch them eventually because eventually he'll come out. If they want to charge someone, well, the usual process is they'd go and see someone in the community who's, you know, well-known, wellrespected, you know what I mean? You know, sort of an elder sort of person, whatever, in that regards anyway, and they come around and they just have a yarn to you and say "Look, come up, get charged", you know what I mean? (pers. comm., Aboriginal informant).

In this case, the State representative of the Aboriginal Land Council in the Far West, Tombo Winters, acted as the intermediary.

So, like we had our trust in Tombo. We knew like, even though the police, we didn't trust the police - there was no way in the world we trusted anything they said or believed anything they said - but it was only because that Tombo came around, you know, and he reinforced the point that no-one will be arrested, no-one will be locked up, you know what I mean? (pers. comm., Aboriginal informant).

Negotiation is added to evasion as a strategy for those who, ultimately know they can neither invert nor negate the exercise of police sovereignty. What is equally evident is the distrust and anger directed at the police. There is a real hatred of perceived abuses of power.

Policing in the Far West is not seen as a neutral idiom through which the State's intentions are transmitted. Through negotiation of their subordinate position, concessions can be gained. The important aspect of this negotiation was that they were not arrested and locked up. As it was stressed:

We didn't want to get locked up, that was the main - that was our main priority and we told that to Tombo and we stressed that on a number of occasions ....(pers. comm., Aboriginal informant).

The members of the Brewarrina 17 were initially charged in the courthouse at an informal bail hearing. As they explained to me, the police sat behind a table and read out the charges and those accused were bailed, which meant they walked out and left. What is of 
interest is not so much the expectation of violence, which may or may not eventuate, but the constant state of anticipation of violence. Police and Aborigines understand violence as a condition of existence; it is only the terms and conditions in which it is meted out that are at issue. The anxiety of a fantasy of menace is participated in on both sides of the divide.

The exercise of contingent jurisprudence inverts the authority of the State. The dictates of the margins prevail and must be acted upon. The aberrations or abuses of State power affirm local specificity and the arbitrariness needed to uphold State sovereignty. The refusal of or non-compliance with police authority by Aborigines amplifies an adherence to alternate forms of sovereignty, to a muted, uncertain and inscrutable other way of life. It shadows and gives meaning to the astonishing revelation made at the RCIADIC of the spectre of Aboriginal terrorism violently disrupting the Bicentenary celebrations. Paradoxically, the arbitrariness is needed to exercise the State's own sovereign rule. The cultural borderlands of the Far West in the 1980s, which the nation glimpsed briefly in the RCIADIC reports, emerged from a world where social hierarchies and social distance were redrawn rather than suspended. Hierarchy and difference were reaffirmed through State institutions through the 'breaches' that constituted differential treatment. The reality of a social landscape of the 1980s was one of struggle and tension, where its measurable and calculable, rational and ordered demarcations merged with the spectres that inhabit a more intangible, but no less real labyrinthine world which existed in the imaginations of police. It was no longer a question of the strength of the borders between community/self and other, but living with the anxiety of the impossibility of achieving previous forms of closure.

\section{NOTES}

1. I would like to acknowledge the assistance given to me by $\mathrm{Dr} \mathrm{T}$. Ernst and Dr K. Zubrinich who carried out the original research into the Brewarrina 'riot' with me in 1991. The collaborative research provided the inspiration for this article. I also would like to thank them for their comments on earlier drafts of this article which have been most useful. I also thank Dr Gillian Cowlishaw, Dr Andrew Lattas, Dr Robert lrvine and an anonymous reviewer for their patient reading and constructive comments on this article. The University of Newcastle provided financial support for research to complete this project.

2. The RCIADIC was established in August, 1987 as a national inquiry by the Federal Government into the number of Aboriginal deaths in custody. The original inquiry listed the deaths of 44 Aborigines in police custody to be investigated. The final number was 99 (RCIADIC, National Report, 1991, Vol, 1, p.1).

3. Aboriginal representative bodies were greatly disappointed by the findings of the RCIADIC. The families of those who died in custody have expressed deep dismay and much disillusionment that no police were charged. At the completion of the RCIADIC, both State and Federal Directorates of Public Prosecutions decided to take no action against any of the police officers and prison warders found wanting in the case study reports.

4. Dr T. Ernst, Dr K. Zubrinich and myself carried out the courtroom research for the trial of three defendants and the subsequent appeal in the Supreme Court in March and April, 1991.

5. Two trials arose from these events. The arrest of seventeen Aboriginal people in Brewarrina on the day following the 'riot' led to a lengthy legal process which began in the lower courts and was not completed in the NSW Court of Criminal Appeal (CCA) until November, 1994. Those initially charged in Brewarrina Local Court were remanded to appear at Bourke Local Court on December 7th, 1987 (SMH, 24th Sept, 1987). The committal hearing was held at the Local Court at Bourke on the 25th July, 1988, where 17 defendants were committed for trial on a total of 30 charges (SMH, 26th July, 1988). In the first trial, the three accused were charged with offences committed against police officers and each one of the individuals was charged with riotous assembly. The two trials were held in Bathurst District Court in 1991.

6. The front page headlines in the Sydney Morning Herald (SMH), for example, stated boldly 'Blood on the Streets the Night a Town Exploded'. The regional newspaper, the Daily Liberal (Dubbo, NSW), ran a headline reading, 'Alcohol given to Rioting Aborigines: Witness'.

7. The political campaign provided a public forum for the expression of the concern about the 'crime wave' afflicting towns in the Far West of NSW. The campaign sought an increase in the powers of police intervention, regulation and control of public order offences, which disproportionately affected Aboriginal communities. Specifically, the campaign sought the reintroduction of the Summary Offences Act (1970), which had been repealed by the incumbent Labor government in 1979 (see Bonney, 1989).

8. The campaign did not entirely avoid racial slurs. The Deputy Leader of the NSW National Party, Ian Armstrong, made explicit the 'problems' at a public rally, where he stated, 'we got to get rid of crime, drugs, hoons 
and coons' (the latter a derogatory term for Aborigines) (Sunday Telegraph, 21.2.88, cited in Goodall, H. 1990:26).

9. This racial incident occurred in Bourke on the 28th August, 1986. (See Cowlishaw, 1994).

10. The substantial work in exploring this cultural space of ambiguity and multiple meanings in the Far West has been carried out by Cowlishaw (1988).

11. See Cowlishaw (1990) for a consideration of the media treatment of the role of the medical staff.

12. David Gundy died in his bedroom as a result of a gunshot wound he received during a pre-dawn police raid on his family home in Marrickville, a suburb of Sydney. The RCIADIC jurisdiction in this case was challenged by police who claimed Gundy was not in custody when shot. Jurisdiction was affirmed and the inquiry proceeded.

13. For the police there was nothing sinister in this, as it is routine procedure for those with prior involvement with a case to follow it through.

\section{REFERENCES}

BABCOCK, B. 1978. The Reversible World: symbolic inversion in art and society. Ithaca: Cornell University Press.

BONNEY, R. 1989. NSW Summary Offences Act 1988. Sydney: NSW Bureau of Crime Statistics and Research.

CARRINGTON, K. 1991. The Death of Mark Quayle: Normalising Racial Horror in Country Towns and Hospitals. Journal for Social Justice Studies 4:161-188

1990. Aboriginal Girls and Juvenile Justice: What Justice? White Justice. Journal of Social Justice Studies 3:1-18

COWLISHAW, G. 1988. Black, White or Brindle. Sydney: Cambridge University Press

1990. Where is Racism? Journal of Social Justice Studies. 3:51-60

1994. Policing the Races. Social Analysis: 71-92,

CUNNEEN, C. and T. ROBB, 1987. Criminal Justice in North-west New South Wales. Sydney: NSW Bureau of Crime Statistics and Research.

FOUCAULT, M. 1980. Power/Knowledge. ed. Gordon, C. Sussex: Harvester Press.

1984. The History of Sexuality. Harmondsworth: Penguin.

1987. Discipline and Punish. Harmondsworth: Penguin

GOODALL, H. 1990. Policing in Whose Interests, Journal for Social Justice Studies. 3:19-34

HOGG, R. 1991. Policing and Penality. Journal for Social Justice Studies 4:1-26

KRISTEVA, J. 1982. Powers of Horror: an essay on abjection. New York: Columbia University Press

MARCUS, J. 1991. Under the Eye of the Law, Journal of Social Justice Studies 4:117-132

NSW Anti-Discrimination Board. 1982. Report on the Study of Street Offences by Aborigines. Sydney: Government Printers

PRATT, M.L. 1992. Imperial Eyes: Travel Writing and Transculturation. London: Routledge

STALLYBRASS, P. and A. White, 1995. The Poetics and Politics of Transgression. Ithaca: Cornell University Press.

TAUSSIG, M. 1989. Terror as Usual. Social Text. 23:3-20

VIDLER, A. 1992. The Architectural Uncanny: essays in the modern unhomely. Cambridge: MIT Press

WOOTTEN, H. 1991. Report of the Inquiry Into the Death of David John Gundy (Royal Commission Into Aboriginal Deaths In Custody) Canberra: Australian Government Publishing Service.

1991a. Regional Report of the Inquiry In New South Wales, Victoria and Tasmania (Royal Commission Into Aboriginal Deaths In Custody). Canberra: Australian Government Publishing Service.

1991b. Report of the Inquiry Into the Death of Lloyd James Boney (Royal Commission Into Aboriginal Deaths In Custody). Canberra: Australian Government Publishing Service.

1991c. Report of the Inquiry Into the Death of Mark Anthony Quayle (Royal Commission Into Aboriginal Deaths In Custody). Canberra: Australian Government Publishing Service.

WILSON, E. 1988. Aspects of Aboriginal Interaction with Criminal Justice System in Wilcannia and the Far West Region, Submission to Royal Commission into Aboriginal Deaths in Custody. Western Aboriginal Legal Service: 32

YOUNG, I. 1990. Justice and the Politics of Difference. Princeton: Princeton University Press. 